\title{
Reactive Oxygen Species Cerebral Autoregulation in Health and Disease
}

\author{
Maia Terashvili ${ }^{1}$, Phillip F. Pratt ${ }^{2}$, Debebe Gebremedhin ${ }^{1}$, Jayashree Narayanan ${ }^{1}$, and David \\ R. Harder ${ }^{1}$ \\ 1 Department of Physiology, Medical College of Wisconsin, Milwaukee, WI 53226 \\ 2 Department of Anesthesiology and Pharmacology and Toxicology and Cardiovascular Research Center, \\ Medical College of Wisconsin, Milwaukee, WI 53226
}

\begin{abstract}
Superoxide and other oxygen radicals (ROS) derived from the oxidative metabolism of L-arginine influence cell signaling and gene expression. In some tissue ROS stimulate structural changes, such as proliferation, hypertrophy, or remodeling. ROS production within the developing CNS stimulates excitation and in vascular tissue causes contraction. The effect of ROS-induced autoregulatory failure in the CNS following hypoxic-ischemic encephalopathy, seizures, trauma, or stroke in children leads to acute mortality and chronic morbidity.
\end{abstract}

\section{Production and effects of ROS on the cerebral vasculature}

Regulation of nutritive blood flow to metabolically active tissue is a vital process supplying substrate for enzymatic production of intermediates to maintain cellular homeostasis. In the brain, neuronal metabolism relies almost exclusively on oxidative pathways requiring adequate delivery of oxygen and glucose. Under normal ranges of physiological blood pressure, cerebral blood flow to the brain remains constant despite fluctuations in transmural pressure. This autoregulation is largely a function of signaling events in the vessel wall such that increasing arterial pressure depolarizes and activates arterial muscle keeping flow relatively constant $(1-4)$.

Reactive oxygen species are believed to be involved in cellular signaling in blood vessels in both normal and pathological states. The major pathway for the production of ROS is by way of the one-electron reduction of molecular oxygen to form an oxygen radical, the superoxide anion $\left(\mathrm{O}_{2}{ }^{-}\right)$. Within the vasculature, there are several enzymatic sources of $\mathrm{O}_{2}{ }^{-}$, including xanthine oxidase, the mitochondrial electron transport chain, and nitric oxide (NO) synthases (5). Studies in recent years, however, suggest that the major contributor to $\mathrm{O}_{2} \cdot{ }^{-}$levels in vascular cells is the membrane-bound enzyme NADPH-oxidase (6). Produced $\mathrm{O}_{2}{ }^{-}$can react with other radicals, such as $\mathrm{NO}$, or spontaneously dismutate to produce hydrogen peroxide $\left(\mathrm{H}_{2} \mathrm{O}_{2}\right)$ (7). In cells, the latter reaction is an important pathway for normal $\mathrm{O}_{2} \cdot{ }^{-}$breakdown and is usually catalyzed by the enzyme superoxide dismutase (SOD). Once formed, $\mathrm{H}_{2} \mathrm{O}_{2}$ can

Address Correspondence To: David R. Harder, PhD Professor and Director of Cardiovascular Center, Department of Physiology, Medical College of Wisconsin, 8701 Watertown Plank Rd. Milwaukee, WI-53226, Phone: 414-456-5611; FAX: 414-456-6515; E-mail:

dharder@mcw.edu.

Maia Terashvili, PhD, Phone: 414-456-5723, E-mail: mterashv@ mcw.edu

Phillip F. Pratt, PhD, Phone: 414-456-5644, E-mail: ppratt@ mcw.edu

Debebe Gebremedhin, PhD, Phone: 414-456-5715, E-mail: mariyei@ mcw.edu

Jayashree Narayanan, M.S., Phone: 414-456-8094, E-mail: jay@ mcw.edu 
undergo various reactions, both enzymatic and non-enzymatic. The anti-oxidant enzymes catalase and glutathione peroxidase act to limit ROS accumulation within cells by breaking down $\mathrm{H}_{2} \mathrm{O}_{2}$ to $\mathrm{H}_{2} \mathrm{O}$. Metabolism of $\mathrm{H}_{2} \mathrm{O}_{2}$ can also produce other, more damaging ROS (8). For example, the endogenous enzyme myeloperoxidase uses $\mathrm{H}_{2} \mathrm{O}_{2}$ as a substrate to form the highly reactive compound hypochlorous acid. Alternatively, $\mathrm{H}_{2} \mathrm{O}_{2}$ can undergo Fenton or Haber-Weiss chemistry, reacting with $\mathrm{Fe}^{2+} / \mathrm{Fe}^{3+}$ ions to form toxic hydroxyl radicals $\left({ }^{-} \cdot \mathrm{OH}\right)$ (8).

ROS are involved in oxidation of lipoproteins, modulation of apoptosis, upregulation of adhesion molecule expression, and activation of the processes involved in vascular remodeling, such as enhancement of vascular smooth muscle growth and activation of matrix metalloproteinases (9). In addition, one of the most powerful acute effects of ROS in the vasculature is the alteration of vascular smooth muscle tone. There is evidence that $\mathrm{O}_{2} \cdot{ }^{-}$can not only constrict (10), but can also dilate cerebral arteries (11). Moreover, several studies have demonstrated clearly that small cerebral arterioles relax in response to the $\mathrm{O}_{2}{ }^{-}$metabolite $\mathrm{H}_{2} \mathrm{O}_{2}(12,13) . \mathrm{H}_{2} \mathrm{O}_{2}$ thus causes powerful dilatation of cerebral arterioles whether applied exogenously or generated endogenously within the vascular wall in response to agonist, such as bradykinin or arachidonic acid $(14,15)$. These dilator responses seem to be mediated primarily by cyclooxygenase-derived ROS, which open potassium channels in the vascular smooth muscle cell membrane to cause hyperpolarization and thus relaxation (14-16). In the cerebral circulation, therefore, $\mathrm{ROS}$ such as $\mathrm{O}_{2}{ }^{-}$and $\mathrm{H}_{2} \mathrm{O}_{2}$ could possibly either dilate or even exert opposing effects on vascular tone. The balance between $\mathrm{O}_{2}{ }^{-}$and $\mathrm{H}_{2} \mathrm{O}_{2}$ in the vascular wall is regulated by the expression and activity of endogenous SOD.

\section{The role of cytochrome P450 enzymes for the production of ROS}

The cytochrome P450 (CYP) enzymes are membrane-bound, heme-containing terminal oxidases that are bound in organism from Archaebacteria to humans. These enzymes are responsible for the metabolic activation or inactivation of most type of drugs and toxins. CYP enzymes are capable of metabolizing endogenous arachidonic acid (AA) into vasoreactive products and are therefore are often referred to as the third pathway of AA metabolism (cyclooxygenases and lipooxygenases being the other two pathways). Much attention thus have been focused on the role of CYP enzymes in vascular homeostasis (17). In addition to the production of vasoreactive AA metabolites, CYP enzymes also generate ROS, such as $\mathrm{O}_{2}{ }^{--}$, $\mathrm{H}_{2} \mathrm{O}_{2}$. For example, released free AA following stimulation of astrocytes with glutamate is converted to epoxyeicosatrienoic acid (EETs) by microsomal epoxygenases (CYP 2C11) or PGI2/Tx by cyclooxygenases. Both these processes generate $\mathrm{O}_{2}{ }^{-}$, which is further metabolized to $\mathrm{H}_{2} \mathrm{O}_{2}$ by superoxide dismutase (SOD). Similarly, stimulation of vascular smooth muscle cell by pressure, stretch, flow and so forth, triggers the release of AA, which is metabolized to 20-HETE by CYP 4A enzyme that can also generate $\mathrm{O}_{2}{ }^{-}$, which is further metabolized to $\mathrm{H}_{2} \mathrm{O}_{2}$ by SOD. ROS thus are produced during metabolism of AA by CYP enzymes and may play an important role in regulation of the tyrosine kinase pathways. Additionally, another recent report provides strong evidence that $\mathrm{O}_{2}{ }^{-}$participates in the endothelium-derived hyperpolarizing factor (EDHF) response of CYP-derived EETs, suggesting that an endothelial epoxygenase homologous to human CYP $2 \mathrm{C} 8 / 9$ is the source of $\mathrm{O}_{2}{ }^{-}$in coronary arteries (17). Release of inhibitory radical species would be expected to inhibit pressure-induced myogenic tone. On the other hand, $\mathrm{O}_{2} \cdot{ }^{-}$has been shown to inhibit NO production, which would enhance myogenic tone (18). Given the potential sources of ROS formation in the form of NADPH P450 oxidases in the cerebral arterial wall, it is important that we define the role of ROS on myogenic mechanisms in the cerebral circulation. 


\section{Action of ROS on ion channels}

Maintenance of cellular ionic gradient is essential to cell survival and function. Apart from maintaining osmotic equilibrium, ion channels are co-transporters that mediate the movement of ions against electrical and concentration gradients and regulate plasma and mitochondrial membrane potential. Plasma membrane potential controls many cell-specific processes. In the brain, the membrane potential controls the active state of arterial muscle, release of paracrine substances from vascular and capillary endothelial cells, neuronal activity, and multiple processes in astrosytes. With respect to arteriolar muscle there are four major $\mathrm{K}^{+}$channel isoforms: $\mathrm{Ca}^{2+}$-activated $\mathrm{K}^{+}$channels, delayed rectifier $\mathrm{K}^{+}$channels, inwardly rectifying $\mathrm{K}^{+}$ channels, and ATP-sensitive $\mathrm{K}^{+}$channels (19). Upon patch clamping freshly isolated cerebral arteriolar muscle the major $\mathrm{K}^{+}$channel isoform present is $\mathrm{K}_{\mathrm{Ca}}$. If analogy with other excitable cells is assumed, it is the inwardly rectifying $\mathrm{K}^{+}$channel that is largely responsible for setting the level of membrane potential $(19,20)$. Inhibition of $\mathrm{K}^{+}$channels depolarizes cerebral vascular muscle as defined by the $\mathrm{K}^{+}$equilibrium potential, however $(21,22)$. The major voltage sensitive $\mathrm{Ca}^{2+}$ channel in cerebral arterial muscle is the $\mathrm{L}$-type $\mathrm{Ca}^{2+}$ channel (23). To date we have very little evidence for rapidly inactivating $\mathrm{T}$-type $\mathrm{Ca}^{2+}$ channels in cerebral arterial muscle. There are also several $\mathrm{Cl}^{-}$channels in cerebral arteriolar muscle, and there is increased interest in them with respect to regulation of membrane potential and other cellular processes (24). In this review wefocus on $\mathrm{K}_{\mathrm{Ca}}$ channel.

Free radicals exert direct and indirect actions on ion channels. The redox status of channel proteins has been hypothesized to affect the ion channel activity in arterial muscle $(25,26)$. This hypothesis states that the balance between oxygen and its reactive species functions as an oxygen sensor through actions on ion channels $(26,27)$. In this regard $\mathrm{K}^{+}$channels have been shown to be sensitive to $\mathrm{H}_{2} \mathrm{O}_{2}(26,28-31) . \mathrm{H}_{2} \mathrm{O}_{2}$ has been demonstrated to hyperpolarize arterial muscle by way of activation of maxi $\mathrm{K}_{\mathrm{Ca}}$ by direct and indirect mechanisms $(15,26$, 28-31). In cat, $\mathrm{H}_{2} \mathrm{O}_{2}$ has been shown to activate ATP sensitive $\mathrm{K}^{+}$channels (11). A recent report provides evidence that $\mathrm{H}_{2} \mathrm{O}_{2}$ can function as an EDHF (31). ROS repeatedly have been demonstrated to modulate $\left[\mathrm{Ca}^{2+}\right]_{i}$ on agonist stimulation of $\mathrm{L}-$ type $\mathrm{Ca}^{2+}$ channels, which could be either the primary or secondary target (32). The literature on free radicals and direct action on ion channels as determined by patch clamp or direct measurement of membrane potential is not extensive. Given the importance of membrane potential on cellular control mechanisms, however, this is an area of active investigation.

There are many indirect actions of ROS on vascular membrane potential. Activation/inhibition of ion channels to a large extent depends on channel protein phosphorylation. Both upstream regulators of protein/tyrosine kinases and direct effects on their translocation and activation have been shown to be sensitive to reactive radical species. Tyrosine kinases and phosphatases are targets of $\mathrm{H}_{2} \mathrm{O}_{2}$ as activators and inhibitors (33). $\mathrm{H}_{2} \mathrm{O}_{2}$ can activate ERK1/2 and $\mathrm{p} 38$ MAPK in the presence of agents such as angiotensin $(9,34) . \mathrm{H}_{2} \mathrm{O}_{2}$ also can mediate EGF-induced activation of phospholipase C (PLC) (35). In general, phospholipases are targets of ROS. PLC activity regulates diacilglycerol (DAG) levels, which in turn activates and induces translocation of protein kinase C (PKC) (36). Recent literature demonstrates that ion channel phosphorylation is mediated by kinase activity $(37,38)$. Alteration of PKC, either through DAG or directly, and tyrosine kinase activities induced by ROS would be expected to modulate ion channel activity, resulting in membrane potential responses with downstream modulation of cell functions under membrane potential influence. Similarly, modification of PLC activity changes levels of intracellular inositol triphosphate $\left(\mathrm{IP}_{3}\right)$ affecting $\mathrm{Ca}^{2+}$ release from internal stores. 


\section{Action of ROS on $\mathrm{K}_{\mathrm{Ca}}$ channel activity in cerebral arterial muscle cells}

Activation of arterial smooth muscle is regulated by the level of membrane potential. The plasma membrane potential is set by unequal distribution of ions. Ion species with high relative conductance set the membrane potential in accordance to specific charge and concentration gradients (ie, Nernst potential); in vascular muscle cells $\mathrm{K}^{+}$is the dominant species in this regard. Vascular smooth muscle membrane potential is a major influence in defining the level of activation, and in cerebral arterial muscle cells the major determinant of activation and contraction. Indeed, a $1.0 \mathrm{mV}$ reduction in membrane potential initiates a significant increase in active tension with a correlation coefficient relating change in membrane potential to change in active tension of $0.98(2,3)$. The mechanisms by which ROS modulate ion channels, including $\mathrm{K}_{\mathrm{Ca}}$ channel activity in vascular muscle remain largely unexplored. We have shown that the $\mathrm{K}_{\mathrm{Ca}}$ is a target for $\mathrm{O}_{2} .^{-}$(39). At this time we do not know how $\mathrm{O}_{2} \cdot{ }^{-}$enhance $\mathrm{K}_{\mathrm{Ca}}$ activity; it could act directly on channel proteins or on second messengers, which include PKC and tyrosine kinase, that mediate phosphorylation of $\mathrm{K}_{\mathrm{Ca}}$ channels. Generation of $\mathrm{H}_{2} \mathrm{O}_{2}$ also seems to activate $\mathrm{K}_{\mathrm{Ca}}$ (Debebe Gebremedhin, $\mathrm{PhD}$, and David R. Harder, $\mathrm{PhD}$, unpublished data, 2005). Both $\mathrm{H}_{2} \mathrm{O}_{2}$ and $\mathrm{O}_{2}{ }^{-}$thus act to increase single-channel $\mathrm{K}_{\mathrm{Ca}}$ activity in cerebral vascular muscle cells.

\section{ROS in the brain: actions on functional hyperemia}

The source of ROS in the brain may require CYP enzyme activity and is supported further by data obtained recently in our laboratory using samples of cerebrospinal fluid (CSF) containing the spin trap N-tert-butyl-hydroxylamine, which is selective for $\mathrm{O}_{2}{ }^{-}$(Debebe Gebremedhin, $\mathrm{PhD}$, and David R. Harder, $\mathrm{PhD}$, unpublished data, 2005) and support a recent report that an endothelial CYP isoform (C8/C9) generate $\mathrm{O}_{2} \cdot{ }^{-}$in coronary arteries (40). Given the many cell type in the brain, it is certain that there is no single source of ROS. Whatever the sources of ROS, these free radicals appear to impinge chronically on mechanisms regulating blood flow in the brain; For example, infusion of scavengers, such as SOD, into the CSF increased blood flow as measured by laser-Doppler flowmetry (Debebe Gebremedhin, $\mathrm{PhD}$, and David R. Harder, $\mathrm{PhD}$, unpublished data, 2005)). The effect of SOD on baseline blood flow is most likely attributed to removal of $\mathrm{O}_{2}{ }^{-}$, which potentially enhances nitric oxide. The increase in blood flow was reversed after the infusion was completed (Debebe Gebremedhin, PhD, and David R. Harder, PhD, unpublished data, 2005). The literature would suggest that the source of cerebral $\mathrm{O}_{2} \cdot{ }^{-}$produced would be by way of nitric oxide synthase (NOS) through $\mathrm{NAD}(\mathrm{P})$ $\mathrm{H}$ dependent reductase activity. The CYP NAD $(\mathrm{P}) \mathrm{H}$ reductase, however, is virtually the same as NOS (NOS is a heme containing protein similar to CYP enzyme system). In summary, scavenging of $\mathrm{O}_{2} \cdot{ }^{-}$by infusion of SOD modulates the cerebral blood flow in vivo (Debebe Gebremedhin, PhD, and David R. Harder, PhD, unpublished data, 2005), demonstrating that these molecules participate in the regulation of nutritive blood flow in the brain. Even more dramatic is the action of 30 minute subdural infusion of a cocktail of xanthine/xanthine oxidase/ catalase (X/XO/Cat, $0.2 \mathrm{mM}$ xanthine/20 $\mathrm{mU}$ xanthine oxidase $/ 500 \mathrm{U}$ catalase). We have shown that under control conditions there is significant autoregulation of CSF; however, there is complete inhibition of CSF autoregulation on elevation of arterial pressure following infusion of a cocktail designed to generate excess $\mathrm{O}_{2} \cdot{ }^{-}$as shown by increased fluorescent intensity of ethidium bromide produced by $\mathrm{O}_{2}{ }^{-}$from dihydroethidium (39).

When a membrane-enriched homogenate is exposed to $\mathrm{H}_{2} \mathrm{O}_{2}$ (xanthine/XO) there is a marked and significant reduction in 20-HETE formation by way of CYP $\omega$-hydroxylase (Debebe Gebremedhin, $\mathrm{PhD}$, and David R. Harder, PhD, unpublished data, 2005), which is one of the primary mediators of pressure-induced activation of cerebral arteries $(41,42)$. The action of $\mathrm{O}_{2}{ }^{-}$in inhibiting 20-HETE production in a membrane-enriched solution in which all 
conditions are optimized is most likely attributable to a direct action on CYP $\omega$-hydroxylase activity.

\section{Possible pathogenetic role of intracisternally generated ROS}

Subarachnoid hemorrhage (SAH) results in a high mortality rate; $15 \%$ of patients who have SAH die before reaching the hospital and $30 \%$ die within 24 hours of onset (43). Patients who survive the initial hemorrhage and overcome vasospasms frequently experience persistent cognitive deficits, psychosocial impairments, and a decrease in quality of life as a result of acute brain injury (44). Most of the research has focused on the late phase, however, when vasospasm occurs, whereas the mechanisms of acute brain injury are poorly understood.

Lipid peroxidation and other consequences of increased levels of ROS have been implicated in the cause of cerebral vasospasm after SAH $(45,46)$. The primary contributor to ROS production after $\mathrm{SAH}$ is the autooxidation within the subarachnoid space of oxyhemoglobinto met- $\mathrm{Hb}(47)$. As a direct product of this redox reaction, $\mathrm{O}_{2}{ }^{-}$is converted to highly reactive hydroxide anion $(-\cdot \mathrm{OH})$ through the metal-catalyzed Haber-Weiss and Fenton reactions (48, 49). In support of this theory that ROS are primary pathogens for SAH, various antioxidants have been shown to attenuate cerebral vasospasm in animals and humans (50-54). It also has been shown that intracisternal overproduction of $\mathrm{O}_{2} .^{-}$may initiate or mediate cerebral arterial vasoconstriction and subsequent structural damage (46). Moreover, administration of ferrous $\left(\mathrm{Fe}^{2+}\right)$ or ferric $\left(\mathrm{Fe}^{3+}\right)$ iron chelators was shown to mitigate against cerebral vasospasm, providing evidence that the iron-catalyzed Haber-Weiss and Fenton reactions are involved in the mechanism of ROS generation leading to the occurrence of cerebral vasospasm $(55,56)$. These studies further support the pathogenic role of ROS in cerebral vasospasm after SAH.

In summary, cerebral blood flow is maintained at a constant rate despite fluctuations in arterial pressure. The ability of the cerebral vasculature to autoregulate is primarily the function of the activities of native $\mathrm{K}_{\mathrm{Ca}}$ channel. The $\mathrm{K}_{\mathrm{Ca}}$ channel is also a target for several paracrine factors and various physical forces, which alter cerebral tone. Astrocytes are intermediary cell types that function to increase cerebral blood flow to match the metabolic demand of activated neurons. Channelophathy coupled with functional alteration of the mechanisms regulating cerebral blood flow could lead to stroke or cerebral vasospasm. Knowledge of the mechanism by which the functions of the cerebral circulation are regulated will help to develop new therapies for the treatment of pediatric patients suffering from hypoxic injury, trauma, stroke and other cerebral disorders, including acute infections such as meningitis and encephalitis (57).

\section{Acknowledgements}

We gratefully acknowledge the following grants PO1 HL6876, PO1 HL59996, RO1 HL33833 supported by the NIH/ NHLBI and the Veterans administration grant 3440-06P.

\section{References}

1. Bohlen HG, Harper SL. Evidence of myogenic vascular control in the rat cerebral cortex. Cir Res 1984;55:554-59.

2. Harder DR. Comparison of electrical properties of middle cerebral and mesenteric artery in cat. Am J Physiol 1980;239:C23-6. [PubMed: 7395983]

3. Harder DR, Gilbert R, Lombard JH. Vascular muscle cell depolarization and activation in renal arteries on elevation in transmural pressue. Am J Physiol 1998;253:F778-81. [PubMed: 2444115]

4. McCarron JG, Osol G, Halpern W. Myogenic responses is independent of endothelium in rat pressurized posterior cerebral arteries. Blood Vessels 1989;26:315-19. [PubMed: 2635067] 
5. Cai H, Harrison DG. Endothelial dysfunction in cardiovascular diseases: The role of oxidant stress. Circ Res 2000;87:840-4. [PubMed: 11073878]

6. Griendling KK, Sorescu D, Ushio-Fukai M. NAD(P)H oxidase. Role in cardiovascular biology and disease. Circ Res 2000a;86:494-501. [PubMed: 10720409]

7. Griendling KK, Sorescu D, Lassegue B, Ushio-Fukai. Modulation of protein kinase activity and gene expression by reactive oxygen species and their role in vascular physiology and pathophysiology. Arterioscler Thromb Vasc Biol 2000b;20:2175-83. [PubMed: 11031201]

8. Wolin MS. Interaction of oxidants with vascular signaling systems. Arterioscler Thromb Vasc Biol 2000;20:1430-42. [PubMed: 10845855]

9. Cheeseman KH, Slater TF. An introduction to free radical biochemistry. Br Med Bull 1993;49:48193. [PubMed: 8221017]

10. Cosentino F, Sill JC, Katusic ZS. Role of superoxide anions in the mediation of endotheliumdependent contractions. Hypertension 1994;23:229-35. [PubMed: 8307634]

11. Wei EP, Kontos HA, Beckman JS. Mechanisms of cerebral vasodilation by superoxide, hydrogen peroxide and peroxynitrite. Am J Physiol 1996;271:H1262-6. [PubMed: 8853367]

12. Leffler CW, Busija DW, Armstead WM, Mirro R. $\mathrm{H}_{2} \mathrm{O}_{2}$ effect on cerebral prostanoids and pial arteriolar diameter in piglets. Am J Physiol 1990;258:H1382-7. [PubMed: 2337173]

13. Wei EP, Kontos HA. $\mathrm{H}_{2} \mathrm{O}_{2}$ and endothelium-dependent cerebral arteriolar dilation. Implications for the identity of endothelium-derived relaxing factor generated by acetylcholine. Hypertension 1990;16:162-9. [PubMed: 2379949]

14. Sobey CG, Heistad DD, Faraci FM. Potassium channels mediate dilatation of cerebral arterioles in response to arachidonate. Am J Physiol 1998;275:H1606-12. [PubMed: 9815067]

15. Sobey CG, Heistad DD, Faraci FM. Mechanisms of bradykinin-induced cerebral vasodilatation in rats. Evidence that reactive oxygen species activate $\mathrm{K}^{+}$channels. Stroke 1997;28:2290-5. [PubMed: 9368578]

16. Iida Y, Katusic ZS. Mechanisms of cerebral arterial relaxations to hydrogen peroxide. Stroke 2000;31:2224-30. [PubMed: 10978056]

17. Fleming I, Michaelis UR, Bredenkotter D, Fisslthaler B, Dehghani F, Brandes RP, Busse R. Endothelium-derived hyperpolarizing factor synthase (cytochrome P450 2C9) is functionally significant source of reactive oxygen species in coronary arteries. Circ Res 2001;88:44-51. [PubMed: 11139472]

18. Kojda G, Harrison D. Interaction between NO and reactive oxygen species: pathophysiological importance in atherosclerosis, hypertension, diabetes and heart failure. Cardiovasc Res 1999;43:56271. [PubMed: 10690328]

19. Nelson MT, Quayle JM. Physiological roles and properties of potassium channels in arterial smooth muscle. Am J Physiol 1995;268:C799-822. [PubMed: 7733230]

20. Trieschmann $\mathrm{U}$, Isenberg G. $\mathrm{Ca}^{2+}$-activated $\mathrm{K}^{+}$channels contribute to the resting potential of vascular myocytes. $\mathrm{Ca}^{2+}$-sencitivity is increased by intracellular $\mathrm{Mg}^{2+}$-ions. Pflugers Archv 1989;414:S18384. [PubMed: 2780254]

21. Brayden JE, Nelson MT. Regulation of arterial tone by activation of calcium-dependent potassium channels. Science Wash DC 1992;256:532-35.

22. Marshal JJ, Kontos HA. Endothelium-derived relaxing factor: A prospective from in vivo data. Hypertension 1990;16:371-86. [PubMed: 2170274]

23. Gebremedhin D, Lange AR, Narayanan J, Aebly MR, Jacobs ER, Harder DR. Cat cerebral arterial smooth muscle cells express cytochrome P450 4A2 enzyme and produce the vasoconstrictor 20HETE which enhances L-type Ca2+ current. J Physiol 1998;507:771-81. [PubMed: 9508838]

24. Nelson MT, Conway MA, Knot HJ, Brayden JE. Chloride channel blockers inhibit myogenic tone in rat cerebral arteries. J Physiol 1997;502:259-64. [PubMed: 9263908]

25. Berzezinska AK, Gebremedhin D, Chilian WM, Kalyanaraman B, Elliott SJ. Peroinitrite inhibits large conductance $\mathrm{Ca}^{2+}$-activated $\mathrm{K}^{+}$channels in rat cerebral arterial muscle cells. Am $\mathrm{J}$ Physiol 2000;278:H1883-90.

26. Bychkov R, Pieper K, Ried C, Milosheva M, Bychkov E, Luft FC, Haller H. Hydrogen peroxide, potassium currents and membrane potential in human endothelial cells. Circulation 1999;99:171925. [PubMed: 10190882] 
27. Bychkov R, Gollasch M, Stienke T, Ried C, Luft FC, Haller H. Calcium-activated potassium channels and nitrate-induced vasodilation in human coronary arteries. J Pharmacol Exp Ther 1998;285:29398. [PubMed: 9536024]

28. Barlow RS, El-mowafey AM, White RE. $\mathrm{H}_{2} \mathrm{O}_{2}$ opens $\mathrm{BK}_{\mathrm{Ca}}$ channels via the PLA2-arachidonic acid signaling cascade in coronary artery smooth muscle. Am J Physiol 2000;279:H475-83.

29. Barlow RS, White RE. Hydrogen peroxide relaxes porcine coronary arteries by stimulating $\mathrm{Bk}_{\mathrm{Ca}}$ channel activity. Am J Physiol 1998;275:H1283-89. [PubMed: 9746477]

30. Hayabuchi Y, Nakaya Y, Matsuoka S, Kuroda Y. Hydrogen peroxide-induced vascular relaxation in porcine coronary arteries is mediated by $\mathrm{Ca}^{2+}$-activated $\mathrm{K}^{+}$channels. Am J Physiol 1998;13:9-17.

31. Metoba T, Shimokawa H, Nakashima M, Hirakawa Y, Mukai Y, Hirano K, et al. Hydrogen peroxide is an endothelium-derived hyperpolarizing factor in mice. J ClinInvest 2000;106:1521-30.

32. Graier WF, Hoebel BG, Paltauf-Doburzynska J, Kostner GM. Effect of superoxide anions on endothelial $\mathrm{Ca}^{2+}$ signaling pathways. Arteriosc Thromb Vasc Biol 1998;18:1470-79.

33. Wolin MS. Interaction of oxidants with vascular signaling systems. Arterioscle Thromb Vasc Biol 2000;20:1430-42.

34. Zafari AM, Ushio-Fukai M, Akers M, Yin Q, Shah A, Harrison DG, et al. Role of NADPH/NADPH oxidase-derived $\mathrm{H}_{2} \mathrm{O}_{2}$ in angiotensin II-induced vascular hypertrophy. Hypertension 1998;32:488895.

35. Servitja JM, Masgrau R, Pardo R, Sarri E, Picatoste F. Effects of oxidative stress on phospholipid signaling in rat cultured astrocytes and brain slices. J Neurochem 2000;75:788-794. [PubMed: 10899956]

36. Gopalakrishna R, Jaken S. Protein kinase C signaling and oxidative stress. Free Radic Biol Med 2000;28:1349-61. [PubMed: 10924854]

37. Shubert R, Noack T, Serebrykov VN. Protein kinase $\mathrm{C}$ reduces $\mathrm{K}_{\mathrm{Ca}}$ current of rat tail artery smooth muscle cells. Am J Physiol 1999;276:C648-58. [PubMed: 10069992]

38. Shipston MJ, Armstrong DL. Activation of protein kinase C inhibits calcium-activated potassium channels in rat pituitary tumor cells. J Physiol 1996;493:665-72. [PubMed: 8799890]

39. Zagorac D, Yamaura K, Zhang C, Roman RJ, Harder DR. The effect of superoxide anion on autoregulation of cerebral blood flow. Stroke 2005;36:2589-94. [PubMed: 16293785]

40. Fleming I, Michaelis UR, Bredenkotter D, Fisslthaler B, Dehghani F, Brandes RP, Busse R. Endothelium-derived hyperpolarizing factor synthase (cytochrome P450 2C9) is functionally significant source of reactive oxygen species in coronary arteries. Cir Res 2001;88:44-51.

41. Gebremedhin D, Lange AR, Lowry TF, Taheri MR, Birks EK, Hudetz AG, et al. Production of 20HETE and its role in autoregulation of cerebral blood flow. Circ Res 2000;87:60-5. [PubMed: 10884373]

42. Kauser K, Clark JE, Masters BS, Ortiz de Montellano PR, Ma YH, Harder DR, Roman RJ. Inhibitors of cytochrome P450 attenuate the myogenic response of dog renal arcuate arteries. Circ Res 1991;68:1154-63. [PubMed: 1901255]

43. Boderick JP, Brott T, Tomsick T, Miller R, Huster G. Intracerebral hemorrhage more than twice as common as subarachnoid hemorrhage. J Neurosurg 1993;78:188-91. [PubMed: 8421201]

44. Hutter BO, Kreitschmann-Andermahr I, Gilsbach JM. Health-related quality of life after aneurismal subarachnoid hemorrhage: impacts of bleeding severity, computerized tomography findings, surgery, vasospasm and neurological grade. J Neurosurg 2001;94:241-51. [PubMed: 11213961]

45. Asano T, Sasaki T, Koide T, Takakura K, Sano K. Experimental evaluation of the beneficial effect of an antioxidant on cerebral vasospasm: the effect of an antioxidant on cerebral vasospasm. Neurol Res 1984;6:49-53. [PubMed: 6147779]

46. Mori T, Nagata K, Ishida T, Ohami H, Asano T. Superoxide anions in the pathogenesis of talc-induced cerebral vasocontraction. Neuropathol Appl Neurobiol 1995;21:378-85. [PubMed: 8632832]

47. MacDonald RL, Weir BKA. A review of hemoglobin and the pathogenesis of chronic cerebral vasospasm. Stroke 1991;22:971-82. [PubMed: 1866764]

48. Haber F, Weiss J. The catalytic decomposition of hydrogen peroxidase by iron salts. Proc R Soc Lond A $1934 ; 147: 332-51$.

49. Fenton HJH. Oxidation of tartaric acid in the presence of ion. J Chem Soc 1894;23:899-10. 
50. Shishido T, Suzuki R, Qian L, Hirakawa K. The role of superoxide anions in the pathogenesis of cerebral vasospasm. Stroke 1994;25:864-68. [PubMed: 8160234]

51. Fadel MM, Foley PL, Kassell NF, Lee KS. Histidine attenuates cerebral vasospasm in a rabbit model of subarachnoid hemorrhage. Surg Neurol 1995;43:52-8. [PubMed: 7701424]

52. Watanabe T, Nishiyama M, Hori T, Asano T, Shimizu T, Masayasu H. Ebselen ameliorates delayed cerebral vasospasm in a canine two-hemorrhage model. Neurol Res 1997;19:563-65. [PubMed: 9329038]

53. Germano A, Imperatore C, D’ Avella D, Costa G, Tomasello F. Antivasospastic and brain-protective effects of a hydroxyl radical scavenger (AVS) after experimental subarachnoid hemorrhage. J Neurosurg 1998;88:1075-81. [PubMed: 9609303]

54. Saito I, Asano T, Sano K, Takakura K, Abe H, Yoshimoto T, et al. Neuroprotective effect of an antioxidant, ebselen, in patients with delayed neurological deficits after aneurysmal subarachnoid hemorrhage. Neurosurgery 1998;42:269-77. [PubMed: 9482177]

55. Arthur AS, Fergus AH, Lanzino G, Mathys J, Kassell NF, Lee KS. Systemic administration of the iron chelator deferiprone attenuates subarachnoid hemorrhage-induced cerebral vasospasm in the rabbit. Neurosurgery 1997;41:1385-91. [PubMed: 9402590]

56. Horky LL, Pluta RM, Boock RJ, Oldfield EH. Role of ferrous iron chelator 2,2'-dipyridyl in preventing delayed vasospasm in a primate model of subarachnoid hemorrhage. J Neurosurg 1998;88:298-303. [PubMed: 9452239]

57. Potts MB, Koh SE, Whetstone WD, et al. Traumatic injury to the immature brain: potential therapeutic target. Neuron RX 2006;3:143-53. 